\title{
ENVIRONMENTAL CONDITON, FISH RESOURCES AND MANAGEMENT OF MANINJAU LAKE OF WEST SUMATERA
}

\author{
Sulastri, Dede Irving Hartoto dan Ivana Yuniarti \\ Research Centre for Limnology, Indonesian Institute of Sciences \\ Received October 13-2011; Received in revised form June 4-2012; Accepted June 6-2012 \\ email: lastri@indo.net.id
}

\begin{abstract}
A blooming of Microcytis aeruginosa occurred in Maninjau Lake in 2000. Mass fish killed happened frequently due to deterioration of water quality in this lake. This study is aimed to observe the current environmental condition, fishery resources status and the state of development process of comanagement regime in Maninjau Lake. Water quality parameter such as temperature, conductivity, turbidity, $\mathrm{pH}$ and dissolved oxygen (DO) were measured in situ by using Horiba U-10 water checker. Total nitrogen, ammonia, nitrate, nitrite, total phosphorous, orthophosohate and chlorophyll-a parameter were analyzed using standard method. Phytoplankton was analyzed by Lackey Drop Microtransect. Fish samples were obtained from fishers' catch. Fisheries data were collected by enumerator, through Focus Group Discussion (FGD), and questioner list methods. Stakeholder analysis was conducted by focus group interview and discussion. In general, water quality parameters were suitable for the life of aquatic organisms except for DO and ammonia. These parameters indicated that the water quality of lake was still undergoing degradation process. Maninjau Lake is rich of nutrient as indicated by abundance of blue green algae. Bada fish (Rasbora argyrotaenia) is an important commodity and the fisheries significantly contributes to local people' income. Current fisheries problems indicate the urgency of the management and conservation efforts. Several stakeholder groups showed their interest in management. The increment of institutional sustainability concern was reflected by the emergence of local wisdom and the demand for participatory development and management.
\end{abstract}

\section{KEYWORD : Water quality, fisheries resources, management, Maninjau Lake}

\section{INTRODUCTION}

Lake Maninjau, a tecto-volcanic type lake, is an eutrophic lake where the massive blooming of Microcytis aeruginosa (blue green algae) occured in 2000 (Syandry, 2000). It seems that the current cage culture activities caused the increase of the organic material level then stimulated blue green algae growth. This culture system had been developed continuously since 1990 until 1997. During those periods, some environmental problems of Maninjau Lake have emerged as indicated by blooming microalgae and mass fish kill tragedy (Syandry, 2000).

Maninjau Lake has a natural purification phenomenon called tubo belerang. Tubo belerang happens through up-welling and down-welling process triggered by strong wind coming from Southern part. The wind then lifts up the water from hypolimnion and brings it to the epilimnion water column. Finally, the water is discharged to the outlet of the lake or Batang Antokan.

From 1983 Maninjau Lake supplies waters to Maninjau Hydroelectric Power Plant. Natural purification system was disturbed due to existence of power plant. The history of environmental problems and management measures has been studied by Hartoto (2009). One of the problems identified by the author is the destruction of social capital among the people living in the surrounding Maninjau Lake. Some efforts to resolve the problem of the lake have been initiated since 2001 such as by opening the weir, so the discharge also flows through its natural outlet to enable to control algae bloom (Sulastri, 2002a).

Fisheries activities are dominated by fish cage culture that is rapidly developed excessing the capacity limit. The carrying capacity of cage culture was estimated in this lake around 1,500 units (Hartoto \& Ridwansyah,2001). However the number of cage culture reached to 9,825 units in 2006 and as the result, a mass fish killed happened in 2009. The fish killed tragedy might be due to deterioration of water quality, caused by the excessive number of cage. The water revealed clearer condition resulted by waters quality monitoring. The monitoring results showed that water quality changed gradually from 2005 to 2006 . Moreover, the trophic state also changed from mesotrophic in 2005 to eutrophic condition in 2006 (Triyanto et al., 2006).

To reduce the number of floating cages, District Agam local government issued Local Regulation No

Corresponding author:

Komplek Indonesian Institute For Sciences Cibinong,

Jl. Raya Bogor Jakarta, Km 46 Cibinong, Bogor. 
22 in 2009. Ownership of cages was limited to having two units per person. In addition, the cages should be installed at $50 \mathrm{~m}$ from the lake shore (Peraturan Bupati Agam No 22, 2009). Hartoto (2009) indicated that inappropriate economic development regime which more emphasizes on capitalistic-neoliberalistic system also contributed significantly to environmental problems in Maninjau Lake. Therefore, a suitable participating management regime should be developed in this lake for fishery resources sustainability. This study aimed to elucidate the current environmental condition, fishery resources status and development process of co-management regime in Maninjau Lake, especially the foundation for stakeholder involvement.

\section{MATERIALS AND METHODS}

The Maninjau Lake is pointed out as a research location related to a problem solving in fishery management of inland fisheries. This lake is a tectovulcanic lake, located at $462 \mathrm{~m}$ above sea level, with the surface area of 9737.50 ha with average depth of about $105.5 \mathrm{~m}$ and its maximum depth of $165 \mathrm{~m}$ (Fachrudin et al. 2002). Environmental data was collected at littoral zone of several sites in 2009. Littoral zone is the important area used for cage culture and fishing activities. The location and condition of the sites are presented in Fig. 1 and Table 1. Some data were also collected from secondary sources such as formal reports and scientific publications.

Water quality parameters such as temperature, conductivity, turbidity, $\mathrm{pH}$ and dissolved oxygen (DO) were measured in situ by using Horiba U-10 water checker. The samples were taken by Snatch Bottle sampler at the surface and Secchi depth layers. Water samples for analyzing nitrogen, ammonia, nitrate, total phosphorous, orthophosohate and chlorophyll-a parameter were preserved and analyzed in the laboratory according to Standard Method (Grinberg et al., 1992). Methods for nutrient and other parameters analysis are outlined in Table 2 . To collect phytoplankton, 2 liters of water were filtered with plankton net ( $40 \mu \mathrm{m}$ mesh size). These samples were then preserved in $1 \%$ Lugol's solution. Phytoplankton species was identified according to Prescott (1951), Scott \& Prescott (1961), Baker \& Fabro (1999) and Gell et al., (1999).

Fish samples were obtained from fisher's catch, while fisheries data were collected through enumerator, Focus Group Discussion (FGD), and questioner list methods. Stakeholder analysis was conducted by focus group interview, focus group discussion and questioner list as proposed by FAO (2005).

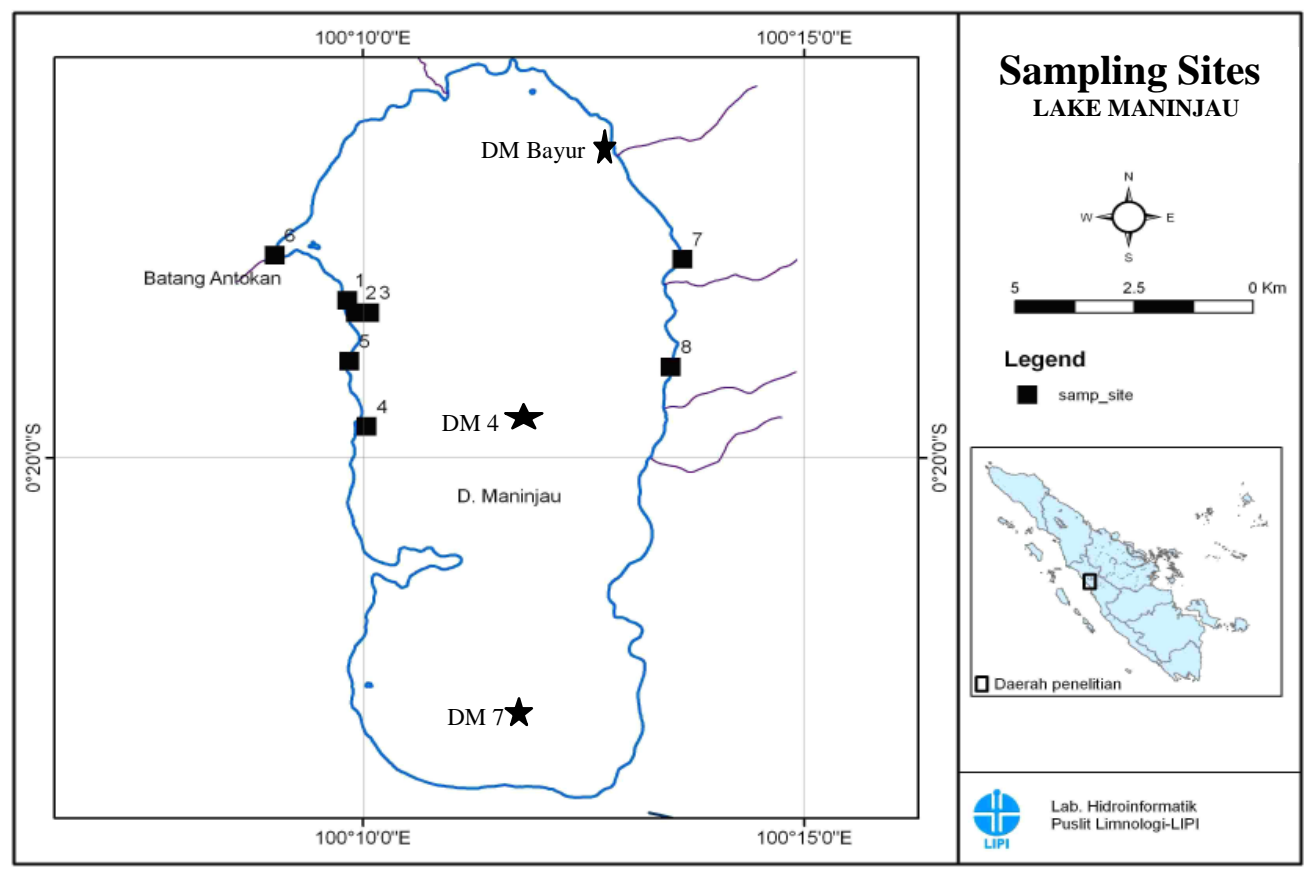

Figure Sampling Sites.

Note: $\downarrow$ Sampling sites for survey on 2009

Sampling sites for survey by Sunanisari (2009) 
Table 1. Sampling Sites physical description

\begin{tabular}{|c|c|c|}
\hline Station & Name of station & Sampling sites' physical description \\
\hline 1 & Batu Anjing & $\begin{array}{l}\text { Fishing area for bada fish (Rasbora } \\
\text { argyrotaenia). Riparian condition is human } \\
\text { settlement and sorounded by many trees. }\end{array}$ \\
\hline 2 & Sawah Panjang & $\begin{array}{l}\text { Fishing area for bada fish and no cage culture } \\
\text { farming }\end{array}$ \\
\hline 3 & The front of Sawah Panjang Site & $\begin{array}{l}100 \mathrm{~m} \text { from Sawah Panjang Site, no cage } \\
\text { culture farming }\end{array}$ \\
\hline 4 & Sigiran & $\begin{array}{l}\text { The area for cage culture farming and riparian } \\
\text { is human setlement area }\end{array}$ \\
\hline 5 & $\begin{array}{l}\text { The proposed area for brush park fishery } \\
\text { system ("Rasau") }\end{array}$ & $\begin{array}{l}\text { Nearby of cage culture farming and human } \\
\text { settlement area }\end{array}$ \\
\hline 6 & Muko - Muko & $\begin{array}{l}\text { A conservation area for bada fish, nearby of } \\
\text { outlet of lake }\end{array}$ \\
\hline 7 & $\begin{array}{l}\text { The front of Limnological Station of } \\
\text { Indonesian Institute of Sciences }\end{array}$ & $\begin{array}{l}\text { Located quite far from cage culture activities. } \\
\text { Riparian is an agricultural area }\end{array}$ \\
\hline 8 & The front of Hotel Tan Dirih & $\begin{array}{l}\text { Habitat of bada fish, nearby cage culture. The } \\
\text { riparian condition is restaurants, human } \\
\text { settlement, and small inlets of lake. }\end{array}$ \\
\hline 9 & DM Bayur & Located on cage culture farming \\
\hline 10 & DM 4 & The middle part of lake. \\
\hline 11 & DM 7 & The deepest part of lake. \\
\hline
\end{tabular}

Table 2. Methods and instrument for water quality analysis in the laboratory

\begin{tabular}{|c|c|c|}
\hline No. & Parameter & Method \\
\hline 1 & Ammonia N-NH & Phenate Method \\
\hline 2 & Nitrate $\left(\mathrm{N}-\mathrm{NO}_{3}\right)$ & Brucine method \\
\hline 3 & Nitrite $\left(\mathrm{N}-\mathrm{NO}_{2}\right)$ & Sulphanilamide method \\
\hline 4 & Total N (T-N) & $\begin{array}{l}\text { Pre digested by } \\
\text { peroxodisulphate and } \\
\text { analysis by Brucine } \\
\text { method }\end{array}$ \\
\hline 5 & Total P (T-P) & $\begin{array}{l}\text { Pre digested by } \\
\text { peroxodisulphate and } \\
\text { analysis by Ascorbic } \\
\text { acid }\end{array}$ \\
\hline 6 & $\mathrm{P}-\mathrm{PO}_{4}$ & Ascorbic acid method \\
\hline 7 & Alkalinity & Titrimetric \\
\hline 8 & Suspended solid & Gravimetric \\
\hline 9 & Chlrophyll-a & Colorometric \\
\hline 10. & Phytoplankton & Lackey Drop \\
\hline & & Microtransect \\
\hline
\end{tabular}

\section{RESULTS AND DISCUSSION}

\section{Environmental Condition}

Water quality condition is presented in Appendix 1. In general water quality parameters are still suitable for the life of aquatic organisms except for DO and ammonia. Temperature and $\mathrm{pH}$ commonly found for tropical lake were also common in this lake and according to Goldman \& Horne, (1983) and Harris, (1986), the $\mathrm{pH}$ ranges from 6 to 9 .

Most of the DO concentration values were below the standard concentration of DO for fisheries as regulated by The Government Regulation of Republic of Indonesia (Peraturan Pemerintah No 20, 1990). The low concentration of DO in April may be related to the impact of organic material degradation originated from fish pellet residues or rotten fish resulted from mass fish kill occurred in February 2009.

Vertical distribution of DO in April at pelagic and littoral zone is presented in Figure 2. In pelagic zone (DM4 and DM7) high DO concentration was found in 0-10 m depth (3.71-6.79 mg/L) and low DO concentration $(<2 \mathrm{mg} / \mathrm{L})$ in $20 \mathrm{~m}$ depth. In littoral zone or in the area of cage culture (DM Bayur) low DO concentration was found in $10 \mathrm{~m}$ depth (Sunanisari, 2009). The low DO concentration near by the upper column water could ascend to the surface waters and caused fish killed when the tubo belerang phenomenon occurred in Maninjau Lake. In 2005, low dissolved oxygen was found in $40 \mathrm{~m}$ depth while in 2007 , low concentration of $D O(<2 \mathrm{mg} / \mathrm{L})$ moved to the upper column (20 m depth 2007) (Triyanto el al., $2005 ; 2007)$. Based on DO concentration, water quality of this lake was under continuous degradation. 

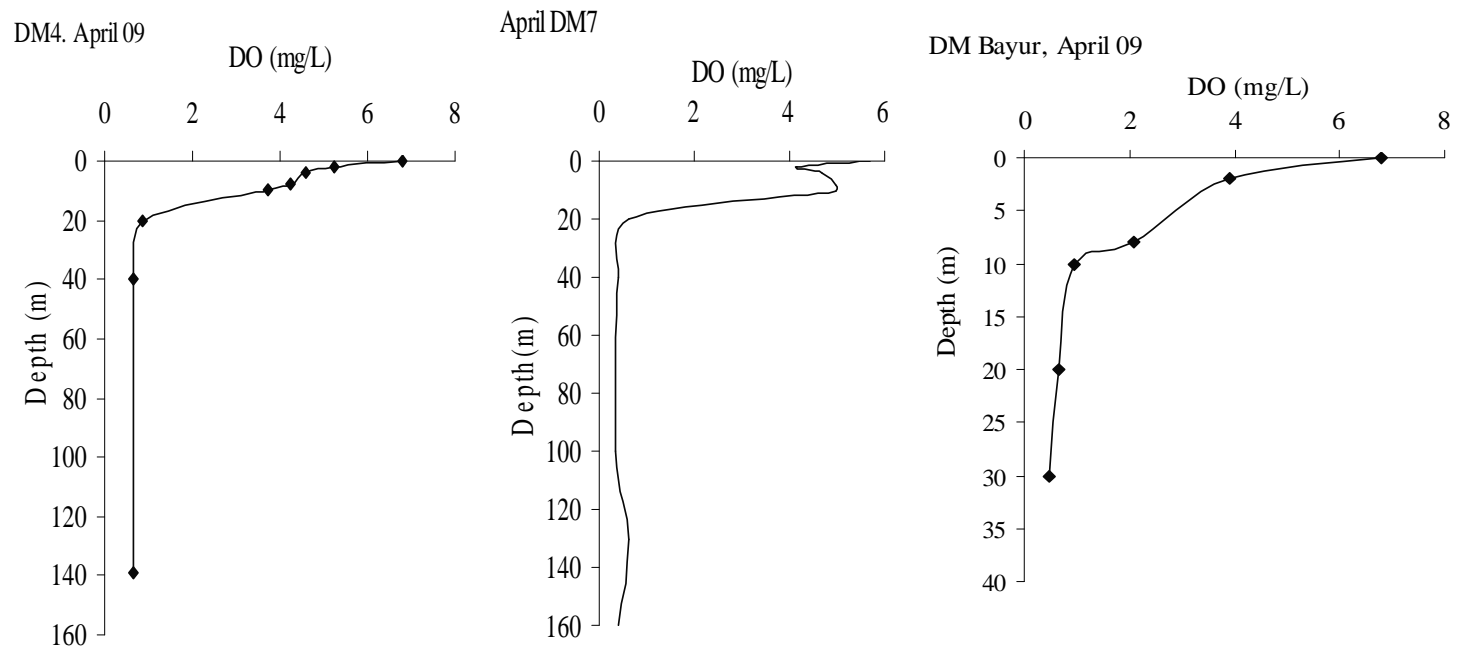

Figure 2. Vertical distribution of dissolved oxygen concentration at pelagic zone (DM4 and DM7) and littoral zone (DM Bayur) in April, 2009 (Sunanisari, 2009).

Conductivity was commonly found in freshwater ecosystem and according to Boyd (1982) it ranged from 0.025 to $0.500 \mathrm{mS} / \mathrm{cm}$. Water turbidity values showed a normal condition. Wood \& Armitage (1997) reported that in the United State, the turbidity level for living aquatic organism range from 5 to 25 NTU. Alkalinity value ranged from 39.27 to $126.85 \mathrm{mgCaCO}_{3} /$ $L$ and the high values were found in July. Alkalinity is influenced by $\mathrm{pH}$ and as shown by the observation of $\mathrm{pH}$.

Nitrite $\left(\mathrm{N}-\mathrm{NO}_{2}\right)$ was less than $0.06 \mathrm{mg} / \mathrm{L}$ or below the standard concentration of nitrite for fisheries while almost in all observation sites, ammonia concentrations exceeded $0.02 \mathrm{mg} / \mathrm{L}$ or above the standard value for fisheries (Goverment Regulation No 20/1990). The distribution of ammonia is highly seasonal and spatially variable depending upon the level of productivity and the extent of pollution of organic mater (Wetzel, 2001). High concentration of ammonia in these observation sites could be influenced by riparian and littoral activities such as human settlement and aquaculture activities. The high concentration of nitrate was found in April that may be caused by runoff sources. Nitrate is usually not toxic in lake up to $1 \mathrm{mg} / \mathrm{L}$ (Goldman \& Horne, 1983).

Most concentrations of total nitrogen (T-N) and total phosphorous (T-P) indicate that Lake Maninjau is rich in nutrient. According to Swedish Environmental Protection Agency (SEPA, 1991), the level of Total Nitrogen $>1.5 \mathrm{mg} / \mathrm{L}$ and Total Phosphor $>0.05 \mathrm{mg} / \mathrm{L}$ indicate that an aquatic system is rich in nutrient. Concentration of orthophosphate $\left(\mathrm{P}-\mathrm{PO}_{4}\right)$ was lower than nitrogen compound concentration. It was caused by the adsorption process between the reactive orthophosphate and sediment or particulate particles (Goldman \& Horne, 1983).

In April TN/TP ratio was more than 12. It indicates that phosphorous is a limiting factor. In contrast, TN/ TP ratio was less than 12 in July indicating nitrogen as limiting factor (Jorgensen, 1980). If nitrogen is the limiting factor for algae growth, then nitrogen fixing of blue green algae occurs frequently (Harris, 1986). This condition is supported by this observation, especially at Station 2, 4 and 8 where dominant micro algae was blue green algae (Cyanophyta) (Figure 3 ).

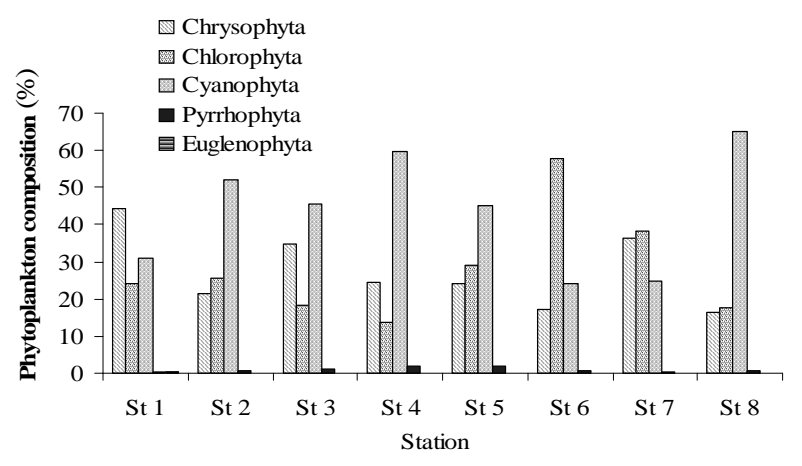

Figure 3. Phytoplankton composition of Maninjau Lake.

Chlorphyll-a concentration ranged from 1.241 to $9.533 \mathrm{mg} / \mathrm{m}^{3}$. This level is similar to the concentration level observed in 2001 which ranged from 0.000 to $9.999 \mathrm{mg} / \mathrm{m}^{3}$ (Sulastri, 2002b). During that time, the dominant blue green algae (Cyanophyta) was replaced by the green algae (Chlorophyta) and then changed to diatom (Chrysophyta) (Sulastri 2002a). Meanwhile, 
in this observation phytoplankton was dominated by blue green algae (Cyanophyta) (Figure 3). Increasing level of blue green algae or Cyanobacteria biomass is often coupled by the production and release of toxic material that may cause the animal and human poisoning (Roland et al., 2005).

\section{Fish resources}

Fish resources found in Maninjau Lake is presented in Table 3. Bada fish (Rasbora argyrotaenia) is an important commodity for capture fisheries in Maninjau Lake because its high market value especially as smoked fish product. The price of smoked bada reaches up to 140,000 IDR/kg (Dina, 2008), this indicates that the fish significantly contributes an important income to local people. Monthly production and the value of smoked bada are presented in Table 4. Smoked bada production depends on the fishers's catch and usually some of their catch is also consumed as fresh form to support local demand and fisher's family.

Table 3. Fish resources of Lake Maninjau (Triyanto, 2003)

\begin{tabular}{llll}
\hline \multicolumn{1}{c}{ Local Name } & \multicolumn{1}{c}{ Scientific Name } & Family & \multicolumn{1}{c}{ Common name } \\
\hline Barau & Hampala macrolepidota & Cyprinidae & Hampala barb \\
Garing & Tor soro & Cyprinidae & Barb \\
Asang & Osteochilus haselti & Cyprinidae & Hard lipped barb \\
Bada & Rasbora argyrotaenia & Cyprinidae & Silver Rasbora \\
Mas & Cyprinus casio & Cyprinidae & Common carp \\
Kalui & Osphronemus goramy & Osphronemidae & Giant gourami \\
Rinuak & Psylopsis sp. & & \\
Mujair & Oreochromis mossambicus & Cichlidae & Mozambique Tilapia \\
Supareh & Puntius sp. & Cyprinidae & Barb \\
Nila & Oreochromis niloticus & Cichlidae & Nile tilapia \\
Gabus & Ophiocephalus sp. & Ophiocephalinidae & Snakeheads \\
Panjang / sidat & Anguilla sp. & Anguillidae & Shortfin eel \\
Puyu, betook & Anabas testudineus & Anabantidae & Climbing perch \\
Indosiar & Oxyeleotris marmorata & Eleotridae & Marbled goby \\
Baung & Mystus sp. & Bagridae & Redtail catfish \\
Pensi & Corbicula & Corbiculidae & Asian clam \\
\hline
\end{tabular}

a) Bada is caught by traditional gears such as gill net and trap named lukah. This fish lives in littoral zone; hence, it is easily caught by traditional gear. Besides the traditional gears, Bagan (a lift net) is also operated to catch this fish. This gear is considered as an unenvironmentally friendly fishing device that is presumed to disturb fish population balance in lake if the number of gear and mesh size of the gear is not controlled. Bagan was designed to catch small fish as found in Towuti Lake (Nasution, 2008). Important captured fishes in Maninjau are bada and rinuak. Both fishes are categorized as small fishes seizing $7-10 \mathrm{~cm}$ and $5 \mathrm{~mm}$ respectively.

b) Observation by local people indicated that the size of bada gets smaller by the years. The decrease of fish size may be caused by the overwhelming number of new fishers following the tragedy of fish killed in cage culture. Increasing number of small fish is supported by length frequency analysis conducted by Dina (2008). This study showed that the exploitation rate of bada was already higher than optimal exploitation. This situation indicates the urgency of the management and conservation efforts in Lake Maninjau

c) Rinuak (Psylopis sp) is an endemic species and important fisheries commodity in Maninjau Lake. Rinuak is small fish size of around $5 \mathrm{~mm}$ and supports local demand with the price of 25,000 IDR per $\mathrm{kg}$ in off season. Local people inform that, Rinuak was rarely found after fish killed occurred in Lake. In addition, Rinuak is an important fish to sustain the balance of food chain in Lake Maninjau. It is a prey for carnivorous fish such as Hampala barb and Redtail catfish (Yuniarti et al, 2010).

d) Hampala barb, redtail catfish, and hard lipped barb are always found in the local market although not plentiful compared to bada and rinuak. Meanwhile, Nile Tilapia which is a commodity from floating cage culture farming, sometimes also caught in the lake. Nile Tilapia is sold in local market and also outside of Maninjau area. 
e) Marbled goby, another exotic species is currently found by the fishers in this lake. In the other part of Indonesia, marbled goby is a high value exported commodity. The existence of this fish it brought worries on local people about its potential impact of the fish to indigenous species. Study on the food habit revealed that the main food item of this species was zooplankton and mollusks (Corbicula \& Pomacea) (Yuniarti et al., 2010). The study indicated that food webs in Maninjau Lake were still in balance indicated by the completeness of food web components. Therefore, there is no proof to support the local people concern about the negative impacts of this fish on the indigenous fish populations.

f) Asian clam (Corbicula sp.) is sold to support local demand such as restaurant and local households. According to local people, the production of this clam is also declining due to various reasons among of them is cage culture farming at littoral zone. Marbled goby is the predation of clam and shrimp therefore it may become a threat to the production of this clam. It is also suspected that disappearance of shrimp is related to the increasing number of marbled goby.

Table 4. Monthly production and value of smoked production of bada fish in 2009

\begin{tabular}{|c|c|c|c|c|c|c|c|c|}
\hline \multirow{3}{*}{ Fishermen } & \multicolumn{2}{|c|}{ April } & \multicolumn{2}{|c|}{ May } & \multicolumn{2}{|c|}{ June } & \multicolumn{2}{|c|}{ July } \\
\hline & $\begin{array}{c}\text { Smoked } \\
\text { Fish }\end{array}$ & Value & $\begin{array}{c}\text { Smoked } \\
\text { Fish }\end{array}$ & Value & $\begin{array}{c}\text { Smoked } \\
\text { Fish }\end{array}$ & Value & $\begin{array}{l}\text { Smoked } \\
\text { Fish }\end{array}$ & Value \\
\hline & $(\mathrm{Kg})$ & (IDR) & $(\mathrm{Kg})$ & (IDR) & $(\mathrm{Kg})$ & (IDR) & $(\mathrm{Kg})$ & (IDR) \\
\hline 1 & 17.75 & 2.485 .000 & 17.75 & 2.485 .000 & 18.75 & 2.625 .000 & 16.50 & 2.310 .000 \\
\hline 2 & 21.50 & 3.010 .000 & 25.75 & 3.605 .000 & 19.25 & 2.695 .000 & 20.25 & 2.835 .000 \\
\hline 3 & 17.75 & 2.485 .000 & 17.50 & 2.450 .000 & 12.00 & 1.680 .000 & 23.00 & 3.220 .000 \\
\hline 4 & 15.75 & 2.205 .000 & 15.25 & 2.135 .000 & 19.75 & 2.765 .000 & 16.75 & 2.345 .000 \\
\hline 5 & 13.50 & 1.890 .000 & 30.50 & 4.270 .000 & 29.00 & 4.060 .000 & 21.00 & 2.940 .000 \\
\hline 6 & 16.75 & 2.345 .000 & 53.75 & 7.525 .000 & 24.00 & 3.360 .000 & 23.50 & 3.290 .000 \\
\hline 7 & 32.00 & 4.480 .000 & 62.50 & 8.750 .000 & 45.00 & 6.300 .000 & 15.50 & 2.170 .000 \\
\hline Average & 19.3 & 2.700 .000 & 31.90 & 4.460 .000 & 23.96 & 2.730 .000 & 19.50 & 2.730 .000 \\
\hline
\end{tabular}

Note: Value calculation: fishing activity in 25 days and the price 140,000 IDR

Most aquaculture areas are located at littoral zone where various organisms habit, for instances: mollusks, shrimp, and small fishes (Sulastri et al. 2010). Constructions of floating cage and other activities can destruct littoral habitat through the declining of water quality and losing of substrate and degradation of the habitats. Study by Yuniarti et al. (2010) indicated that insects were the main food item of most species, including carnivorous fish such as hampala barb, redtail catfish and marbled goby. However, it was shown by a study in other lakes (e.g. lake Ranau and Lake Bojongsari) conducted by Sulastri (2000) and Sulastri (1989) that these species mainly consumed fresh water shrimp (Macrobrachium spp.). The difference of the diets is probably related to the declining of shrimp species that may be caused by the destruction of the littoral zone of the lake.

Aquaculture activities in the lake are subject to local government regulation such as cage culture area should be $50 \mathrm{~m}$ from the shore (Bupati Agam Regulation No 22/2009). However, other sources of problems in the littoral zone utilization in Maninjau
Lake come from construction of restaurants, hotels and human settlement in littoral zone. These issues are extremely important issues to be awared. Therefore, a co-management regime must be developed to overcome such issues. This regime is a powerful tool to balance and share the benefits and obligations for all stakeholders. The importance of the participatory mangement has been underlined by Fisheries Law No 31/ 2004 (Bab2, Article 2)

\section{Management of Maninjau Lake}

Hartoto (2009) has identified that Maninjau Lake supports eleven social functions that should be managed harmoniously. Those social functions are aesthetic, education, culture, environmental health, spiritual, individual resilience, collective resilience, economic (fisheries, electricity, water supply, tourism industry) and recreation. The economic generation services especially cage culture fisheries drives various problems; for instances: algae bloom occurrence, fish kill, and social conflict in 2000 (Syandry, 2000). 
Hartoto (2009) identified that the roots of the problems are the destruction of social capitals and the lack of the implementation of divine value system in daily life.

Co-management, defined as the sharing of management responsibility between local government and local user to manage a resource such as fisheries (FAO, 2005). In Indonesia, the success of comanagement has been shown by Panglima laut (Aceh), Awig-Awig (Lombok), and Nila Jaya Group (Malahayu Reservoir, Brebes). Maninjau Lake should be counted as a candidate for the implementation of co-management system involving all stakeholders.

Co-management of natural resources needs a plan to be developed through participative planning process involving government and local community. Therefore, initiation of co-management process, identification of the roles, functions, capacities and barriers of involvement of each stakeholder is very important. Concerning that matter, a stakeholder analysis has been done to identify those criteria as shown in Appendix 2. In addition, a diagram showing the degree of interest and the role of identified stakeholders is presented in Figure 4.

From the data shown in Table 5 and Figure 4, it appeared that the stakeholder groups having high interest on the resources (fishers and other fisheries entrepreneurs) tend to have lower role in the management of the lake. Meanwhile, formal institutions; for instances, local planning agency and local institutions: have the higher role in the management process although they have low interest on the resources. Furthermore, it is clearly shown in Figure 5 that cage culture farmers are the main players on the management of the lake. Importantly, the natural resources division of Agam District Gov. possesses the lowest role and interest in the management system. It indicates that there is no strong power of this institution to make and enforce the regulation related to sustainability of natural resources. Hence, sustainability of natural resources seems to be the less priority or is almost neglected by the stakeholders

Fishers appear to have lower role in the management despite they are one of the main users of the lake resources. The main reason of their low role is their low capacity (capitals, power, etc.) to be involved in the past management regime (Appendix 2). Therefore, in the co-management system, the role of this group should be enhanced, because they have the indigenous knowledge regarding the resources. Possession of indigenous knowledge is an imperative capital to elevate the success of co-management in a certain area. Similar reason can be applied to explain the other fisheries entrepreneurs, low role, their limitation of capital and knowledge also prevents them from being actively involved in the management process.

It has been largely known that local institutions (e.g. local planning agencies and sub-district government) have difficulties to enforce regulation in this area. However, the involvement of Kerapatan Adat Nagari and their ability to create networking with various stakeholders are powerful to develop their role in the management system.

In spite of their limitation involvement in the management system, cage culture farmers are the most capitally powerful groups among stakeholders; therefore, they have higher role than other resource users. However, their less knowledge about the natural system and they being legitimate to enforce the rules to other resource users, their role is less than formal institution. Thus, this group is proposed as one of the main groups that should be involved more actively in the co-management system. It is unfortunate that other stakeholders such as hotel and restaurant owners are not included in this research. Their participation is imperatively important in the next research.

Indicators of success were also obtained from this stakeholder survey. The results are shown in Table 5. Surprisingly, most of the mentioned indicators belong to the ecological sustainability indicators of Charles (2001). According to this author, there are four categories indicating the success of co-management implementation, namely ecological sustainability, community sustainability, institutional sustainability, and socio-economic sustainability indicators

Moreover, institutional sustainability indicators were also recognized by the respondents such as the emerging of local wisdom and the demand for participative development. These results are quite encouraging because respondents seemed to be aware of the environmental condition, in addition to the economic concern. Overall, it can be concluded that the respondents are also alarmed by the deterioration of the lake environment. This awareness is a very important factor that should be maintained for the establishment of co-management in Maninjau Lake area. 
Table 5. Indicators of the success of Maninjau Lake management

\begin{tabular}{cll}
\hline No. & \multicolumn{1}{c}{ Identified Indicator } & \multicolumn{1}{c}{ Categories } \\
\hline 1 & Sustainability & $\begin{array}{l}\text { Ecological, socio-economic, } \\
\text { institutional, and community }\end{array}$ \\
2 & Benefit provision for local people & Socio-economic \\
3 & Benefit provision for local government & Socio-economic \\
4 & Clean and clear water and environment & Ecological \\
5 & Survival of floating cage culture and other businesses & Socio-economic \\
6 & Emerging of local people' awareness to the environmental & Ecological and community \\
7 & Solving all problems & Institutional \\
8 & Emerging of people' responsibility & Ecological and community \\
9 & Reduction of floating cages & Ecological \\
10 & Participative development & Institutional \\
11 & Disappearance of water odor & Ecological \\
12 & Well functioning ecosystem & Ecological \\
13 & Lake resilience as before the existing of floating cage & Ecological \\
14 & Development and application of local wisdom & Institutional \\
\hline
\end{tabular}

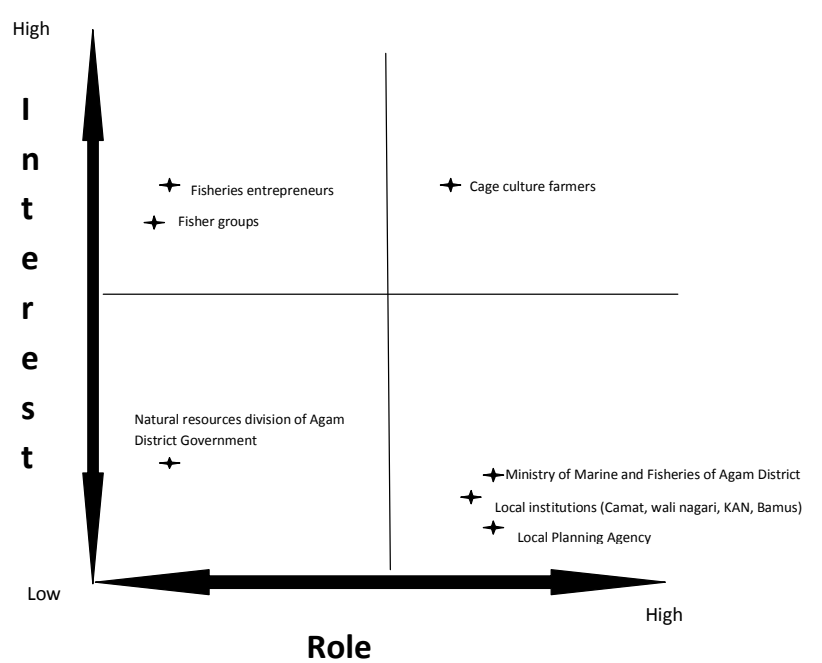

Figure 4. Degree of role and interest of some stakeholders in Lake Maninjau.

\section{CONCLUSION}

In general some water quality parameters are still suitable for the life of aquatic organisms except DO and ammonia indicating that the water quality of lake was under continuous degradation. Maninjau Lake is rich in nutrient concentration as indicated by abundance of blue green algae. The lake contains important fish resources to support the local people life, and Bada fish (Rasbora argyrotaenia) is an important commodity and significantly contributes to local people' income.

Arising fisheries issues in this lake call for management and conservation action. There were some stakeholder groups that have different degree on interest and role of management. Institutional sustainability indicators were also recognized by the respondents such as the emergence of local wisdom and the demand for participative development in management.

\section{REFERENCES}

Boyd, C.E. 1982. Water quality in pond for aquaculture. University of Auburn, Birmingham. $482 \mathrm{pp}$.

Baker, P. D \& L.D. Fabro. 1999. A. guide to identification of common blue green algae (Cyanoprokaryotes) in Australia. Cooperative R.C. for Freshwater Ecology, Identification Guide. 25: $43 \mathrm{p}$.

Charles, A. T. 2001. Sustainable Fishery systems. Fish and aquatic resources series 5. Blackwell Science. $370 \mathrm{pp}$.

Dina, R. 2008. Rencana Pengelolaan Sumberdaya Ikan Bada Rasbora argyrotaenia Berdasarkan Analisis Frekuensi Panjang Di Danau Maninjau. Skripsi. Institut Pertanian Bogor. 76 pp.

Fakhrudin, M., H. Wibowo, L. Subehi \& Ridwansyah. 2002. Karakterisasi hidrologi Danau Maninjau Sumatera Barat Proceeding. Seminar Nasional Limnologi, Bogor, 22 April 2002. Research Centre for Limnology-Indonesian Institute for Sciences. 65-75 pp.

FAO. 2005. Guidelines for designing data collection and sharing systems for co- management fisheries. 
Part 1 Practical guide, Part 2. Technical guidelines. FAO Fisheries Technical Paper. 42 pp.

Gell, P.A, Jason A. Sonneman, M. A. Reid, M. A. Illma \& A.J. Sincock. 1999. An illustration key to Common diatom genera from Southern Australia. $64 \mathrm{pp}$.

Goldman, C.R. \& A.J. Horne.1983. Limnologi. McGraw-Hill Book Company. New York. 464 pp.

Griberg, A.E., Lenores, Cleseri \& A.D. Lation. 1992. Standard Methods for the Examination of Water and Waste Water. $17^{\text {th }}$ ed. Washington.

Harris, G.P. 1986. Phytoplankton ecology, structure, function and fluctuation. Chapman and Hall, London, New York. 384 pp.

Hartoto, D.I. \& I. Ridwansyah. 2001. Penghitungan daya dukung danau atau waduk untuk pengembangan budidaya ikan dalam karamba. Contoh kasus Danau Maninjau. 13 pp.

Hartoto, D.I. 2009. Rejuvenation of local Ecological Wisdom for the development of fisheries comanagement in Lake Maninjau. Paper was presented in The Workshop on "Lembaga Adat di Indonesia: Apakah mereka memiliki peran dalam Pengelolaan Sumberdaya Perikanan dan Wilayah Pesisir", Lombok, Indonesia 2-5 Agustus 2009, International Collective In Support of Fishworkers. $36 \mathrm{pp}$.

Jorgensen, S.E. 1980. Lake Management. Pergamon Press Ltd. Oxford-Great Britain. 167 pp.

Peraturan Pemerintah Republik Indonesia Nomor 20 Tahun 1990. Pengendalian Pencemaran Air. Sekretariat Menteri Negara Kependudukan dan Lingkungan Hidup.

Peraturan Bupati Agam Nomor 22 Tahun 2009. Pengelolaan Danau Maninjau. Lubuk Basung, Februari, 2009. 10 pp.

Prescott, G.W. 1951. Algae of the Western Great Lakes Area. Cranbrook Institute of Science. Bloomfield Hills, Michigan. Bulletin. 31pp.

Roland, A., D.J. Bird \& A. Giant. 2005. Seasonal change in composition of the cyanobacterial community on the occurrence of hepatotoxic blooms in the Eastern township, Quibec Canada. Journal of Plankton Research. 27 (2): 683-694.
Scott, A.M. G.W. Prescott 1961. Indonesian Desmid. Hydrobiologia. XVII

Sunanisari, S., 2009. Karakterisasi Potensi Sumber Daya Perairan Darat Danau Maninjau, Sumatera Barat. Technical Report. Research Centre for Limnology-Indonesian Institute for Sciences. 88 pp.

Swedish Environmental Protection Agency. 1991. Water Quality Criteria for Lake and Water source, A System for Classification of Water Chemistry, Metal Concentration and Organism, 32 pp.

Syandry, H. 2000. Dampak Karamba Jaring Apung Terhadap Kualitas Air Danau Maninjau, Presented in Panel Press Clup (PPC), Padang. 13 pp.

Sulastri .1989. Komposisi, Kelimpahan dan Beberapa Aspek Biologi Fauna Ikan. In A. Nontji \& D.I. Hartoto (Eds), Limnologi Situ Bojongsari. Monografi. 1: 148-159 pp.

Sulastri. 2000. Komposisi dan Jaring-Jaring Makanan Ikan. In D.I. Hartoto \& Sulastri (Eds), Limnologi Danau Ranau. Monografi No 2. Research Centre for Limnology-Indonesian Institutes for Sciences: p 99-108

Sulastri. 2002a. Spatial and Temporal Distribution of Phytoplankton in Lake Maninjau, West Sumatera. Procceding of the International Symposium on Land Management and Biodiversity in South East Asia, September 12-20, 2002, Bali Indonesia. Hokkaido University, Sapporo Japan and R.C. For Biology. Indonesian Institute of Sciences. p 403408.

Nasution, S.H. 2008. Ekobiologi dan Dinamika Stok Sebagai Dasar Pengelolaan Ikan Endemik BontiBonti (Paratherina striataAurich) Di Danau Towuti. Disertasi, Institute Pertanian Bogor, 150 pp.

Sulastri. 2002b. Komposisi, kelimpahan dan distribusi fitoplankton sebagai dasar analisis kondisi pencemaran Danau Maninjau, Sumatera Barat. Proceeding. Seminar Nasional Limnologi. Research Centre for Limnology-Indonesian Institute for Sciences. 22: 255-27 pp.

Sulastri, D.I. Hartoto, I. Yuniarti \& Syahroma H. Nasution. 2010. Karakterisasi Habitat, Kebiasaan Makan dan Sistem Konservasi lkan Bada Rasbora argyrotaenia di Danau Maninjau, Sumatera Barat. A Paper presented in Seminar Nasional Ichthiology 
Indonesia IV, Bogor, 8-9 Juni 2010, Masyarakat Iktiologi Indonesia, 487-497 pp.

Triyanto. 2003. Inventarisasi jenis-jenis ikan yang terdapat di Danau Maninjau Kabupaten Agam Sumatera Barat. Research report. Research Centre for Limnology, Indonesian Institute of Sciences. Unpublished Data. $1 \mathrm{p}$.

Triyanto, D. I. Hartoto, Sulastri, Cynthia H., M. Badjoeri, F. Sulawesty, I. Yuniarti, Y. Mardiyati, S. Nomosatriyo, Sugiarti \& Sutrisno, 2005. Karakteristik limnologi Danau Maninjau pasca program penyehatan danau sebagai dasar kebijakan penyususnan pengelolaan danau berkelanjutan. Technical Report. Research Centre for Limnology-Indonesian Institute for Sciences, $50 \mathrm{pp}$.

Triyanto, D. I. Hartoto, C. Henny., M. Badjoeri, F. Sulawesty, I. Yuniarti, Y. Mardiyati, S. Nomosatriyo, Sugiarti \& Sutrisno. 2006. Karakteristik limnologi Danau Maninjau pasca program penyehatan danau sebagai dasar penyusunan kebijakan. Technical Report. Research Centre for Limnology-Indonesian Institute for Sciences, $54 \mathrm{pp}$.
Triyanto, D. I. Hartoto, Cynthia H., M. Badjoeri, F. Sulawesty, I.Yuniarti, Y. Mardiyati, S. Nomosatriyo, Sugiarti \& Sutrisno. 2007. Kajian Karakteristik Limnologi Danau Maninjau. Technical Report. Research Centre for Limnology-Indonesian Institute for Sciences. 38 pp.

Undang-Undang Repuplik Indonesia No 31, 2004. Pengelolaan Perikanan. 56 pp.

Wetzel, R.G. 2001. Limnology Lake and River Ecosystem. $3^{\text {th }}$ ed. Academi Press., New York. $1006 \mathrm{pp}$.

Wood, P.J. \& Armitage. 1997. Biological Effect of the Sediment in the Lotic Environment, Environmental Management. 21(2): 203-217 pp.

Yuniarti, I, Sulastri \& Sutrisno. 2010. Jaring-Jaring Makan Ikan di Danau Maninjau, Sumatera Barat. Proceeding. Seminar Nasional Limnologi V, 2010. Research Centre for Limnology-Indonesian Institute for Sciences.135-143pp. 


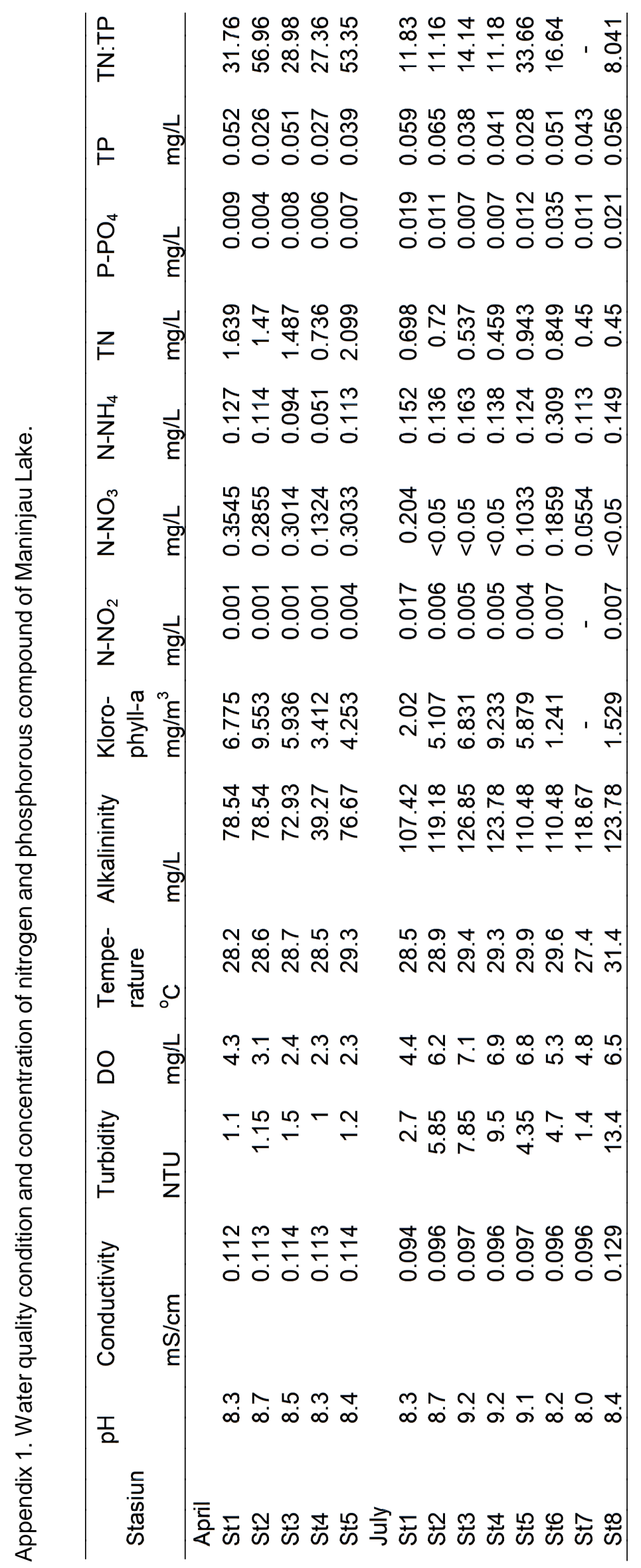




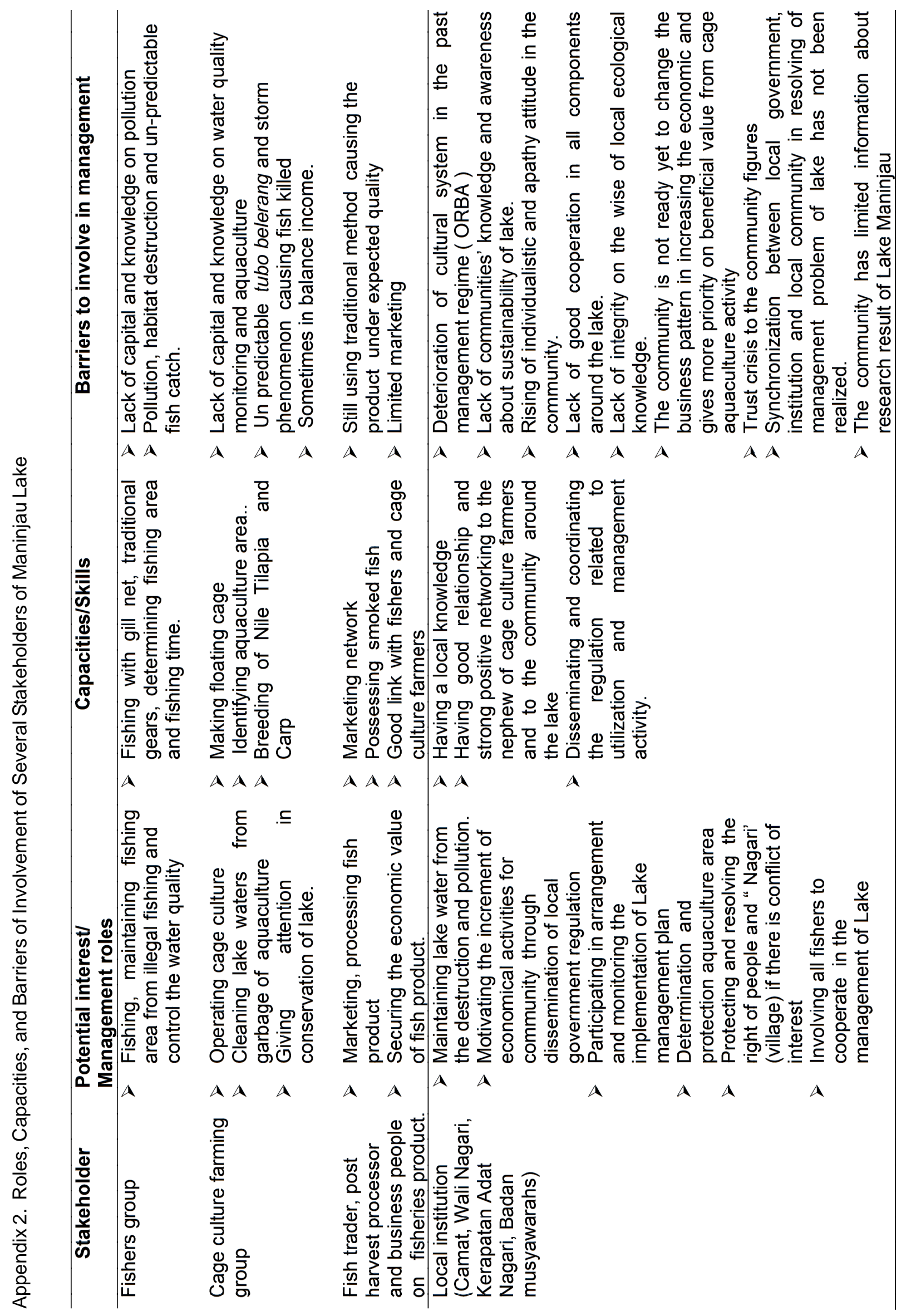

